Maciej Kokoszko (Łódź)

Krzysztof Jagusiak (Łódź)

Jolanta Dybała (Piotrków Trybunalski)

\title{
Bread as FoOd ANd Medicament in Oribasius' Writings
}

$\mathrm{T}$ The Greek word diaita can be translated into English as a way of life ${ }^{1}$. Accordingly, ancient and medieval Greeks gave it a broader meaning than we do today and did not narrow it down to the nutritional schema typical of or recommended to a person. On the other hand, it should be borne in mind that the role of food in this concept was prominent enough to justify the modern simplification of the term.

The foundations of medical knowledge on food are thought to have been laid down by Hippocrates of Cos (V-IV c. BC). As we read, for instance, in the work entitled De alimento, Hippocrates' school promoted the concept that each food simultaneously plays a nutritional and medicinal role ${ }^{2}$. This approach resulted in treating the research into food and into drugs as one, and made foodstuffs a subject of professional discussions ${ }^{3}$,

${ }^{1}$ A Greek-English lexicon, ed. H.G. Liddell, R. Scott, Oxford 1996, p. 356. Cf. E. Craik, Hippocratic diaita, [in:] Food in antiquity, ed. J. Wilkins, D. Harvey, M. Dobson, Exeter 1999, p. 343-350; J. JounnNa, Greek medicine from Hippocrates to Galen, Leiden-Boston 2012, p. 137-141.

${ }^{2}$ Hippocrate, De alimento, 19, 1-2, [in:] Euvres completes d'Hippocrate, ed. E. Littre, vol. IX, Amsterdam 1962. Hippocratic dietetics can be retrieved from treatises included in the Corpus Hippocraticum. On the crucial concepts of the Hippocratic school, cf. V. NutTon, Galen and the traveller's fare, [in:] Food in antiquity..., p. 359-370; IDEM, Ancient medicine, London-New York 2007, p. 72-86, especially 77-85. Concerning the general role of food in Corpus Hippocraticum - S. BYL, L'alimentation dans le Corpus Hippocratique, [in:] Voeding en geneeskunde/Alimentation et médecine. Acten van het colloquium/Actes du colloque Brussel-Bruxelles 12.10.1990, ed. R. JANSEN-SIEBEN, F. Daelmans, Brussels 1993, p. 29-39. Regarding pharmacology in the Hippocratic school, cf. J. Scarborough, Theoretical assumptions in Hippocratic pharmacology, [in:] Formes de pensée dans la collection hippocratique. Actes du IVe Colloque International Hippocratique, Lausanne, September 1981, ed. F. Lasserre, P. Mudry, Geneva 1983, p. 307-325.

${ }^{3}$ Cf. C. Garcia Gaul, Dieta hipocrática y prescripciones alimentarias de los pitagóricas, [in:] Dieta Mediterránea, Comidas y hábitos alimenticios en las culturas Mediterráneas, ed. A. PÉrez Jiménez, G. Cruz Andreotti, Madrid 2000, p. 44-50; F. Pucci Donati, Dieta, salute, calendari. Dal regime stagionale antico ai regimina mensium medievali: origine di un genere nella letterature medica occidentale, Spoleto 2007, p. 17-18; J. JounnNa, Le régime dans la médecine hippocratique: définition, grands problèmes, prolongements, [in:] Colloque. Pratiques et discours alimenatires en Méditerranée de l'antiquité a la renaissance. Actes, ed. J. Leclant, A. Vauchez, M. Sartre, Paris 2008, p. 53-72. 
which over time led to food becoming one of the main points of interest of medical specialists ${ }^{4}$.

A few centuries after the doctor of Cos, Galen (II-III c.) $)^{5}$ adopted the doctrines of his great predecessor ${ }^{6}$ and developed them into an even more complex, but at the same time cohesive system ${ }^{7}$. His theory and practice set out in his writings, exerted an overwhelming influence both on his contemporaries and on his followers.

One of these 'students' was Oribasius $\left(\mathrm{IV}-\mathrm{V}^{\mathrm{th}} \mathrm{c} \text {. }\right)^{8}$. He was not an independent researcher of Galen's calibre but rather a meticulous and skilful compiler. This medical doctor, acting upon the instructions of the Emperor Julian (361-363), whose physician and political collaborator he was, created a voluminous work originally comprising probably some 70 books $^{9}$, which nowadays is referred to as the Collectiones medicae. Later in his life he also composed other versions of his opus magnum, which are today called the Synopsis ad Eustathium filium and the

\footnotetext{
${ }^{4}$ On dietetics before Galen cf. for example K. Bergoldt, Wellbeing. A cultural history of healthy living, transl. J. Dewhurst, Cambridge-Malden, Mass. 2008, p. 30-37, 41-46, 62-72.

${ }^{5}$ On Galen's life and activities cf. for example L. Thorndike, Galen. The man and his times, ScM 14. 1, 1922, p. 83-93; G. SARTON, Galen of Pergamon, Lawrence, KS, 1954, passim; V. Nutton, Galen and medical autobiography, PCPS 198 (New Series no. 18) 1972, p. 50-62; IDEM, The chronology of Galen's early career, CQ 23, 1973, p. 158-171; IDEM, Galen in the eyes of his contemporaries, BHM 58, 1984, p. 315-324; IDEM, Ancient medicine..., p. 222-235; R.J. Hankinson, The man and his work, [in:] The Cambridge companion to Galen, ed. R.J. Hankinson, Cambridge 2008, p. 1-33.

${ }^{6}$ Hippocrates' statement, quoted above, was also cited by Galen himself - Galeni de alimentorum facultatibus 467, 15-16, [in:] Claudii Galeni opera omnia, ed. D.C.G. KüHN, vol. VI, Lipsiae 1823 (cetera: Galen, De alimentorum facultatibus). Concerning the main assumptions of Galenism - V. Nutton, Ancient medicine..., p. 230-247, especially 240-244.

${ }^{7}$ Cf. A. Bednarczy , Galen. Główne kategorie systemu filozoficzno-lekarskiego, Warszawa 1995, passim, especially 49-113. Concerning Galen's dietetic regime - P. Volpe CaCCiatore, El régimen según Galeno, [in:] Dieta Mediterránea..., p. 91-101, especially 91-95.

${ }^{8}$ On Oribasius' life and activities, cf. B. Baldwin, The career of Oribasius, AClas 18, 1975, p. 85-97; M. Grant, Oribasios and medical dietetics or the three ps, [in:] Food in antiquity..., p. 368-379;

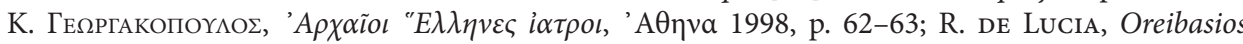
v. Pergamon, [in:] Antike Medizin. Ein Lexikon, ed. K.-H. Leven, München 2005, col. 660-661; M. Koкоszко, Ryby i ich znaczenie $w$ życiu codziennym ludzi późnego antyku i Bizancjum (IV-VII w.), Łódź 2005, p. 14-15; R. De Lucia, Oribasio di Pergamo, [in:] A. Garzya, R. de Lucia, A. Guardasole, A.M. Ieraci Bio, M. Lamagna, R. Romano, Medici byzantini. Oribasio di Pergamon. Aezio d'Amida. Alessandro di Tralle. Paolo d'Egina. Leone medico, Torino 2006, p. 21-29; V. Nutton, Ancient medicine..., p. 295-296; K. JagusiaK, M. Кокоszko, Życie i kariera Orybazjusza w świetle relacji źródłowych, PNH 10. 1, 2011, p. 5-21; IIDEM, Pisma Orybazjusza jako źródło informacji o pożywieniu ludzi w późnym Cesarstwie Rzymskim, VP 33, 2013, p. 339-357.

${ }^{9}$ On the original number of 70 books cf. Oribasius, Synopsis ad Eustathium filium, Prologus, 1, 1-3, [in:] Oribasii synopsis ad Eustathium filium et libri ad Eunapium, ed. I. RAEDER, Leipzig 1964 (cetera: Oribasius, Synopsis ad Eustathium filium); Paulus Aegineta, Prooimion, [in:] Paulus Aegineta, ed. I.L. Heiberg, Leipzig-Berlin 1921, p. 4; Photius. Bibliotheque, ed. R. Henry, vol. I-VIII, Paris 1959-1977, cod. 217, p. 180. Liber Suda in turn refers to 72 books of the Collectiones medicae, cf.

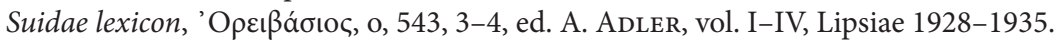


Libri ad Eunapium. Moreover, he complied a work on ancient drug-lore entitled the Eclogae medicamentorum. All of them contain a vast body of information on food and food-based medicaments, including bread, which was in Oribasius' times a staple in the Mediterranean ${ }^{10}$.

The production of bread goes far back in history, and archaeological findings from various parts of the Old World demonstrate that it was already known in the Neolithic era ${ }^{11}$. In addition to other ways of processing cereal grains for consumption such as boiled soups and paps, the baking of the dough made of flour and water (kneaded together and left to bake in a high and constant temperature) was certainly one of the fundamental methods of food preparation in the Mediterranean region. Greek and Romans alike put a premium on bread (especially if made from wheat ${ }^{12}$ ) and referred to it as the most important of all basic foodstuffs, even though there must have been individual preferences, which today appear as entirely elusive ${ }^{13}$. Bread was still highly valued in late antiquity and the Byzantine period ${ }^{14}$. In the sphere of cultural and political influence of the Greek and Roman

\footnotetext{
${ }^{10}$ Although the writings of Oribasius refer to breads produced from different cereals, for the purpose of the present discussion I decided to narrow our interest down to wheat bread, because it was the most extensively covered in the physician's medical theory and generally in doctrines of other medical authors. On the justification of the conclusion and other kinds of bread cf. М. Кокозzко, K. JAGUSIAK, Z. RzEźNICKA, Cereals of antiquity and early Byzantine times. Wheat and barley in medical sources (second to seventh centuries AD), transl. K. WodzińsKa, M. ZAKrZEWski, M. ZyTKA, Łódź 2014, passim; IIDEM, Dietetyka i sztuka kulinarna antyku i wczesnego Bizancjum (II-VII w.), cz. I, Zboża i produkty zbożowe w źródłach medycznych antyku i wczesnego Bizancjum, Łódź 2014.

${ }^{11}$ Cf. A. DAlBy, Food in the ancient world from A to Z, London-New York 2003, p. 58-61; H. McGeE, On food and cooking. The science and lore in the kitchen, New York 2004, p. 517.

${ }_{12}$ The available sources almost unambiguously indicate that the variety in greatest demand across the society was by far the common wheat bread (see the remaining part of the introduction). Greek and Roman civilisations knew also varieties made of other cereal species, but these were considerably less valued than wheat-based products, irrespective of individual consumer preferences, the impact of climate, soil, culinary and agricultural traditions on local communities, and economic factors. See: R. Hunter, D. Koukouzika, Food in Greek literature, [in:] A companion to food in the ancient world, ed. J. Wilkins, R. NAdeAu, Malden, Mass.-Oxford 2015, p. 25. Over the centuries, bread produced on the basis of common wheat flour was becoming more popular than other varieties, see: Pliny, Natural history, XVIII, 14, 74, transl. H. Rackham, W.H.S. Jones, D.E. EIchHolz, vol. I-X, Cambridge, Mass. 1938-1963; M. Leigh, Food in Latin literature, [in:] A companion to food..., p. 49. ${ }^{13}$ N. JASNY, The daily bread of the ancient Greeks and Romans, Osi 9, 1950, p. 227-253; K.D. White, Cereals, bread and milling in the Roman world, [in:] Food in antiquity..., p. 38-43; М. Кокоszко, K. JAGUSIAK, Zboża Bizancjum. Kilka uwag na temat roli produktów zbożowych na podstawie źródeł greckich, ZW 17, 2012, p. 34. Bread as an element of a merry, nourishing and peaceful feast was mentioned by Homer (Homerus, Odyssea, IX, 5-10, [in:] Homerus, Homerica carmina, ed. A. Nauck, vol. II, Berolini 1874); later on it also appeared in artistic descriptions of imaginary worlds, ignorant of hunger and replete with lavishly prepared dishes - see R. Hunter, D. Koukouzika, op. cit., p. 22. ${ }^{14}$ A. DAlby, Flavours of Byzantium, Blackawton-Totnes 2003, p. 77-81; J. Koder, Stew and salted meat - opulent normality in the diet of every day?, [in:] Eat, drink and be merry (Luke 12:19). Food and wine in Byzantium. In honour of Professor A.A.M. Bryer, ed. L. Brubaker, K. Linardou, Aldershot,
} 
civilisations, the consumption of bread grew steadily over the centuries and gradually prevailed over cereal soups and paps ${ }^{15}$. This process can be explained not only by the culinary preferences of consumers. Certainly, also other factors had their impact, including the unwaveringly positive opinion of medical writers concerning the beneficial qualities of most varieties of bread and the way in which they affect the human body (discussed further below) as well as the market ascendancy of cereal species suitable for the production of healthy and palatable high-quality bread (particularly common wheat) ${ }^{16}$. In the imperial period (also during the lifetime of Oribasius) the vast acreage of Roman Egypt and North Africa produced and exported such huge amounts of common wheat grain that wheat bread gradually ceased to be the preserve of the elite or of the inhabitants of the regions where this variety of wheat was traditionally cultivated ${ }^{17}$. However, other species such as barley, emmer wheat or millet continued to be the most basic cereal foodstuff for many people ${ }^{18}$.

Bread was a crucial product on the menu of the ancients and for this reason people in the time of Oribasius knew a significant number of its varieties, which may be categorised in several ways. In terms of the methods of production, bread could be baked in ash, in embers, on coals, in special ovens (kríbanon/klíbanon), on spits, or in stoves (ipnós) $)^{19}$. It was based on various plants, such as common,

Hampshire 2007, p. 65-66; M.L. Rautman, The daily life of the Byzantine Empire, Westport 2006, p. 46; M. Koкoszko, K. JagusiaK, op. cit., p. 34.

${ }^{15}$ See, for example, N. Morley, Trade in classical antiquity, Cambridge 2007, p. 38-39; M. Koкоszko, K. Jagusiak, Z. Rzeźnicka, Cereals of antiquity..., p. 47-49; G. Kron, Agriculture, [in:] A companion to food..., p. 162; P. ErdKamp, Supplying cities, [in:] A companion to food..., p. 184. It has to be noted that the inhabitants of rural areas in Asia Minor included pyroí hefthoí in their diet - it was a wheat-based pap, much more easy to make than bread, the production of which required considerable effort and was much more time-consuming; see GALEN, De alimentorum facultatibus, 498, 5 - 499, 1, Küнn VI; M. Кокоszко, K. Jagusiak, Z. Rzeźnicka, Cereals of antiquity..., p. 125-127.

${ }^{16}$ Por. M. Кокоszko, K. Jagusiak, Z. Rzeźnicka, Cereals of antiquity..., p. 37-39.

${ }^{17}$ See G.E. Rickman, The grain trade under the Roman Empire, [in:] The seaborne commerce of ancient Rome. Studies in history and archaeology, ed. J.H. D'Arms, E.C. KopfF, Rome 1980, p. 261-275; D. Kessler, P. Termin, The organization of the grain trade in the early Roman Empire, EcHR 60, 2007, p. 313-332; E. Tengström, Bread for the people. Studies of the corn-supply of Rome during the Late Empire, Stockholm 1974, p. 14; P. ERdKAMP, The grain market in the Roman Empire. A social, political and economic study, Cambridge 2005, p. 207; M. Koкoszko, K. Jagusiak, Z. Rzeźnicka, Cereals of antiquity..., p. 38-39; P. ErdKAmp, Supplying cities..., p. 184. See also R.J. Forbes, Studies in ancient technology, vol. III, Leiden 1965, p. 92.

${ }^{18}$ On the diversity of cereal species well known and often eaten by ancient Mediterranean people see, for example J.R. HaRLan, The origins of cereal agriculture in the Old World, [in:] Origins of agriculture, ed. C.A. Reed, the Hague-Paris 1977, p. 357-384; D. Zohary, M. Hopf, Domestication of Plants in the Old World. The origin and spread of cultivated plants in West Asia, Europe and the Nile Valley, Oxford 1993, p. 15-85.

${ }^{19}$ A. Cubberley, Bread-baking in ancient Italy. Clibanus and sub testu in the Roman world: Further thoughts, [in:] Food in antiquity..., p. 55-68; A. DALBy, Food..., p. 101; J. Liversidge, Roman kitchens 
emmer, and einkorn wheat, barley, proso millet and other cereals, but also on flour produced from pulses or dates ${ }^{20}$. Some varieties of bread involved the use of yeast in the process of preparing the dough ${ }^{21}$. Other categorisations are based on the type of flour (e.g. white, wholemeal, coarse milled, or unsifted), the additional ingredients used as flavouring (e.g. honey, poppy seed, flax seed, milk, pepper, olive oil) or, finally, the shape and size of loaves offered to consumers ${ }^{22}$.

There must have been a vast array of bread varieties available in late antiquity. Some of them were described in Greek and Roman medical literature. The treatises included in the Corpus Hippocraticum $\left(5^{\text {th }} \mathrm{c}\right.$. BC and later) contained lists of wheat bread types distinguished by the quality of flour (dark and white), its coarseness, the use of yeast and the technology of baking (ipnitai, kribanitai and other) ${ }^{23}$. Barley bread was also mentioned in those texts ${ }^{24}$. The first century writer Dioscurides gave a long list of bread varieties; in addition to other cereal species used for production, wheat bread was divided into several categories (setánios, katharós, semidalites, synkomistós) ${ }^{25}$, some of which were seasoned with flavourings (salt

and cooking utensils, [in:] The Roman cookery book. A critical translation of The art of cooking by Apicius for use in the study and in the kitchen, ed. and transl. B. Flower, E. Rosenbaum, London 1958, p. 29-38; B. Sparkes, The Greek kitchen, JHS 82, 1962, p. 121-137; IDEM, The Greek kitchen: Addenda, JHS 85, 1965, p. 162-163; D. Thurmond, A handbook of food processing in classical Rome. For her bounty no winter, Leiden-Boston 2006, p. 68-72.

${ }^{20}$ M. Koкоszкo, K. Jagusiak, op. cit., s. 36; I. Anagnostakis, The Loaves of the King and the Loaves of Cinderella. Byzantine Tales of Bread in Silk and in Ash, [in:] ...come sa di sale lo pane altrui Il Pane di Matera e i Pani del Mediterraneo Atti del Convegno Internazionale di Studio promosso dall'IBAMCNR nell'ambito del Progetto MenSALe Matera, 5-7 Settembre 2014, ed. A. Pelletieri, Foggia 2014, p. 117-118. M. Koкoszko, J. Dybaєa, K. Jagusiak, Z. Rzeźnicka, Dieta mnichów syryjskich.

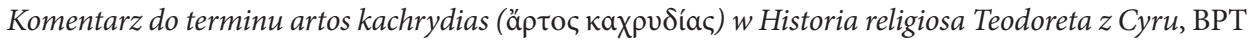
8. 3, 2015, p. 123-156. On breads made of alm dates and legumes and eaten especially by monks see, for example, Athenaei Naucratitae dipnosophistarum libri XV, III, 114 b-c (81, 1-7 KAIBEL), rec. G. Kaibel, vol. I-III, Lipsiae-Berolini 1887-1890 (cetera: Athenaeus of Naucratis, Deipnosophistae); M. DeмвińsкA, Diet: A comparison of food consumption between some Eastern and Western monasteries in the $4^{\text {th }}-12$ th centuries, B 55, 1985, p. 435, 438; S. BRALEWSKI, Od obżarstwa do postu - praktykowanie wstrzemięźliwości od pokarmu przez chrześcijan do VII w., [in:] Dietetyka i sztuka kulinarna antyku i wczesnego Bizancjum (II-VII w.), cz. II, Pokarm dla ciała i ducha, ed. M. KoкoszKo, p. 504. Different kind of untasty bread eaten by monks was that made of common millet, see, for example, Theodoretus, Historia religiosa, II, 4, [in:] Théodoret De Cyr, Histoire des moines de Syrie, vol. I-II, trad. P. Canivet, A. Leroy-Molinghen, Paris 1977-1979; M. Koкoszko, J. Dyba€A, K. Jagusiak, Z. Rzeźnicka, Dieta mnichów syryjskich. Komentarz do terminu ospria (ö $\sigma \pi \rho ı \alpha)$ $w$ Historia religiosa Teodoreta $z$ Cyru, BPT 7. 1, 2014, p. 118.

${ }^{21}$ M. Koкoszko, K. Jagusiak, op. cit., p. 36; I. Anagnostakis, op. cit., p. 115-116.

${ }^{22}$ A treasure trove of relevant information can be found in Book III of Deipnosophistae by Athenaeus; Athenaeus of Naucratis, Deipnosophistae, III, $108 \mathrm{f}-116$ a (73, 2 - 83, 37 Kaibel).

${ }^{23}$ Hippocratis de diaeta, 40, 1-30; 42, 1-27, ed. R. Joly, S. ByL, Berlin 2003 (cetera: De diaeta).

${ }^{24}$ De diaeta, 40, 10-30.

${ }^{25}$ For his views on wheat bread, see: Pedanii Dioscuridis Anazarbei De materia medica libri $V$, II, 85, 1, 7, ed. M. Wellmann, vol. I-III, Berolini 1906-1914 (cetera: Dioscurides, De materia medica) 
or poppy seeds) ${ }^{26}$, also depending on the type of wheat (einkorn ${ }^{27}$, emmer ${ }^{28}$, or spel $\left.t^{29}\right)$. Galen, who wrote over a century later $\left(2^{\text {nd }} / 3^{\text {rd }} \mathrm{c}\right.$. AD), asserted that bread is the most common staple ${ }^{30}$. In his view, common wheat bread was dominant in cities (and was hailed as being the best of all kinds of bread), while other wheat varieties along with other cereal species were used for baking in rural areas ${ }^{31}$. The doctor described the production process, beginning with the selection of grain for milling and the properties of well-kneaded dough ${ }^{32}$, and discussed in more detail the basic kinds of bread. In his account, the wheat bread varieties were divided into white (made of the most refined flour) and dark (made of flour with bran and other impurities ${ }^{33}$; in his view, the best of these was silignites, followed by semidalites, and inferior varieties arranged according to the decrease in quality: autopyrós Isynkomistós, ryparós, and pityrías ${ }^{34}$ ). Coarse and rough flour (chondrites) was also in use $\mathrm{e}^{35}$. Galen mentioned also einkorn wheat bread, which was particularly delicious when still warm $^{36}$, brittle emmer wheat bread ${ }^{37}$, and spelt bread, particularly popular in the countryside ${ }^{38}$. Other varieties referred to in his work included bread made from barley (of various classes depending on the purity of the flour, in the same way as in the case of common wheat) ${ }^{39}$, millet and foxtail millet (used as a last resort, especially in villages) ${ }^{40}$, or rye (known for its rather unsavoury taste and smell, produced by some rural communities in Thrace and Macedonia ${ }^{41}$.

(setánios); De materia medica, II, 85, 1, 7 (katharós); De materia medica, II, 85, 1, 5 (semidalítes); De materia medica, II, 85, 1, 6 (synkomistós).

${ }^{26}$ Dioscurides, De materia medica, II, 85, 2, 7; IV, 64, 1, 1-8.

${ }^{27}$ Dioscurides, De materia medica, II, 89, 1, 3-4.

${ }^{28}$ Dioscuridis Peri haplon farmakon, II, 89, 1, 3-4, [in:] Pedanii Dioscuridis Anazarbei De materia medica libri quanque, ed. M. Wellmann, vol. I-III, Berolini 1914.

${ }^{29}$ Dioscurides, De materia medica, II, 91, 1, 2.

${ }^{30}$ Galen, De alimentorum facultatibus, 493, 14-16, KüHn VI.

${ }^{31}$ Por. Galen, De alimentorum facultatibus, 486, 1-5, KüHN VI; 518, 4-8, KüHN VI.

${ }^{32}$ Galen, De alimentorum facultatibus, 480, 14 - 482, 4, KüHN VI; see also Galeni De victu attenuante, 33, 1 - 34, 1, ed. K. KALbFLEISCH, Leipzig-Berlin 1923.

${ }^{33}$ Galen, De alimentorum facultatibus, 482, 13-15, KüHN VI.

${ }^{34}$ Galen, De alimentorum facultatibus, 484, 1-4, KüHN VI; na temat Galenowej klasyfikacji por. też M. Кокоszко, J. DybaєA, K. Jagusiak, Z. Rzeźnicka, Chleb nieodpowiedni dla chrześcijan: moralne zalecenia Klemensa Aleksandryjskiego w konfrontacji z naukowymi ustaleniami Galena, VP 35, 2015, p. 274-280.

${ }^{35}$ Galen, De alimentorum facultatibus, 496, 14-16, KüHN VI.

${ }^{36}$ Galen, De alimentorum facultatibus, 518, 15, KüHN VI.

${ }^{37}$ Galen, De alimentorum facultatibus, 517, 3, KüHN VI.

${ }^{38}$ Galen, De alimentorum facultatibus, 517, 7-9, KüHN VI.

${ }^{39}$ Galen, De alimentorum facultatibus, 504, 5 - 506, 13, KüHN VI.

${ }^{40}$ Galen, De alimentorum facultatibus, 523, 10-11; see also Galeni in Hippocratis de victu acutorum commentaria libri IV, 876, 1 - 2, Galen, In Hippocratis de victu acutorum commentaria, 876, 1-2, KÜHN XII.

${ }^{41}$ Galen, De alimentorum facultatibus, 514, 14, KüHN VI. 
He also made a distinction with regard to the use of yeast and asserted that the varieties which did not involve its use in production were ultimately inferior ${ }^{42}$. Other distinctions were made on the basis of technology $y^{43}$.

The text in hand will focus exclusively on the work of Oribasius, which may serve as particularly useful source material to illustrate the theory and practice of late antique and early Byzantine doctors with regard to the use of foodstuffs (with an emphasis on bread) in medicine and their dietary prescriptions for preserving or restoring health.

\section{Culinary information on bread}

As for the information on the culinary aspect of bread preparation, Oribasius based his writings on excerpts made from the works of Dieuches (IV ${ }^{\text {th }}$ C. BC) ${ }^{44}$, Athenaeus of Attaleia $\left(\mathrm{I}^{\mathrm{st}} \mathrm{c} \text {. AD) }\right)^{45}$, Antyllus ( $\left.\mathrm{II}^{\mathrm{nd}} \mathrm{c} . \mathrm{AD}\right)^{46}$ and Galen (II $\left.{ }^{\text {nd }} \mathrm{c} . \mathrm{AD}\right)$, while the first and the last of the enumerated authors provide the bulk of the most informative data. However, Galen's prevailing input into the ancient research into bread is underscored by the fact that Oribasius' teachings on the foodstuff follow the pattern imposed by the doctor from Pergamum both doctrinally as well as structurally. Consequently, other authors were introduced only and exclusively to supplement Galen's doctrines.

It is worth noting that Oribasius is fairly precise as far as termini technici describing the food are concerned. He enumerates almost all kinds of bread known to Galen with the exception of ártos ázymos ${ }^{47}$, i.e. unleavened bread, though he was well aware of the differences between leavened and unleavened bread. Thanks to his having made excerpts of the works of Athenaeus of Attaleia, Oribasius also precisely distinguished the term ártos silignites, i.e. common wheat bread ${ }^{48}$ from

\footnotetext{
${ }^{42}$ Galen, De alimentorum facultatibus, 485, 4 - 487, 10, KüHn VI.

${ }^{43}$ Galen, De alimentorum facultatibus, 489, 8 - 490, 1, KüHN VI.

${ }^{44}$ On Dieuches' life see M. Wellmann, Dieuches (3), [in:] RE, Bd. V, Stuttgart 1905, col. 480.

${ }^{45}$ On Athenaeus' life see M. Wellmann, Athenaios aus Attalia, [in:] RE, Bd. II, Stuttgart 1896, col. 2034-2036; E. Kulf, Unterschungen zu Athenaios von Attaleia. Ein Beitrag zur antiken Diätetik, Göttingen 1970, passim; V. Nutton, Athenaeus (6), [in:] Brill's New Pauly. Encyclopaedia of the Ancient World, vol. II, Leiden-Boston 2003, col. 244-245; K.-H. Leven, Athenaios v. Attaleia, [in:] Antike Medizin. Ein Lexikon, hrsg. K.-H. Leven, München 2005, col. 119-120.

${ }^{46}$ On Antyllus' life see A.M. Ieraci Bio, Antyllos, [in:] Antike Medizin..., col. 62-63; V. Nutton, Antyllus, [in:] Brill's New Pauly..., vol. I, Leiden-Boston 2002, col. 810-811.

${ }^{47}$ There is only the general term ázymon pémma, which may - but does not have to - concern unleavened bread - Oribasii collectionum medicarum reliquiae, I, 7, 3, 1-2; III, 3, 1, 3, ed. I. RAEDER, vol. I-IV, Lipsiae-Berolini 1928-1933 (cetera: Oribasius, Collectiones medicae). In any case, the deliberations that we find in Oribasius' writings provide us with information considerably more limited than those surviving in the works of Galen.

${ }^{48}$ For example - Oribasius, Collectiones medicae, III, 13, 5, 1. This bread was also known as aleurites.
} 
ártos semidalites, i.e. durum wheat bread ${ }^{49}$. Moreover, he borrowed from Antyllus and used correctly the term ártos zymites, i.e. leavened bread ${ }^{50}$, which was absent from Galen's treatises.

It is also worth mentioning that Oribasius provides us with two pieces of additional information on ártos plytós, i.e. light bread ${ }^{51}$, which are absent from Galen's treatises. First, and thanks to the information he borrowed from Antyllus ${ }^{52}$, he informs the reader that properly prepared ártos plytós is made from painstakingly purified trimeniaios, i.e. three-month, wheat ${ }^{53}$. Second, it is also interesting to note that Antyllus wrote that ártos plytós was eaten not only in solid form, but also soaked or cooked in water ${ }^{54}$. The latter dish was, however, recommended first and foremost for the ill ${ }^{55}$.

What is more, Oribasius' writings also contain references to ártos dipyros ${ }^{56}$. This term was used to describe twice-baked bread, i.e. hard biscuits (rusks), usually intended for prolonged storage as a food provision. Not much can be said about its features, however, for it was mentioned only once ${ }^{57}$. Let us add that we are indebted for this information to Athenaeus of Attaleia ${ }^{58}$.

As for the technology of producing and baking bread Oribasius preserves two main versions of teachings. The main body of information on bread was taken by Oribasius from Galen's works and constitutes a chapter included in Book I of the Collectiones medicae, entitled Perí árton pyrínon. It was written on the basis of the De alimentorum facultatibus, but Oribasius' version of Galen's teachings is heavily abridged.

The author of the Collectiones medicae started by noting that healthy bread, by which he understood (just like the doctor of Pergamum) ártos pýrinos, is made with a large quantity of yeast (zýme) and salt (halés). It must be very well kneaded before baking in an evenly heated portable kríbanon oven. The taste of bread dough indicates whether the appropriate amount of the abovementioned ingredients was utilised, while an unpleasant gustatory sensation reveals the food's harmful characteristic in respect to the body.

\footnotetext{
${ }^{49}$ For example - Oribasius, Collectiones medicae, III, 13, 6, 1.

${ }^{50}$ Oribasius, Collectiones medicae, IV, 11, 2, 5.

${ }^{51}$ Cf. K. Jagusiak, M. Koкоszko, Z. Rzeźnicka, Cakes and breads in Oribasius' Collectiones medicae, SPP 25. 1, 2015, p. 131.

${ }^{52}$ Oribasius, Collectiones medicae, IV, 11, $1.1-14,4$.

${ }^{53}$ Oribasius, Collectiones medicae, IV, 11, 2, 2-3.

${ }^{54}$ Oribasius, Collectiones medicae, IV, 11, 1, 3 - 2, 1 .

${ }^{55}$ Oribasius, Collectiones medicae, IV, 11, 1, 1. The information agrees with Dieuches' prescriptions concerning bread in general. Compare below.

${ }^{56}$ Cf. K. JagusiaK, M. Koкoszko, Z. Rzeźnicka, op. cit., p. 133.

${ }^{57}$ Oribasius, Collectiones medicae, I, 9, 2, 2-3.

${ }^{58}$ Oribasius, Collectiones medicae, I, 9, 1, 1-3, 3 .
} 
Having finished that part of his treatise, Oribasius goes on to describe ártos plytós ${ }^{59}$. The selected thoughts borrowed from Galen's deliberations are structured so that the description could prove that it is a variety which, though also prepared in the above-presented way, is very different from regular pýros bread owing to its lightness and very limited nutritional properties.

As regards the division of breads according to the baking method, Emperor Julian's friend and physician underlined the fact that Galen had distinguished the following bread categories. The best were kribanitai. Ipnitai breads, i.e. the ones obtained from a regular bread oven, and they came second since they tended to bake not as evenly as kribanitai, and could remain uncooked inside. Third were the kinds baked on the eschára, i.e. a hearth, (and for this reason referred to generally as escharitai). The last were enkryphíai breads, which were subject to the procedure of baking directly in the ashes. Both the latter two varieties were dietetically inadvisable, since they tended to burn on the outside while their inside had a tendency to stay raw ${ }^{60}$.

Oribasius also alluded to the fact that according to Galen the second position after ártoi pýrinoi was held by those types of bread produced from spelt, i.e. ártoi olýrinoi, provided they were produced from a good quality ólyra grain. The last in the line were loaves obtained from einkorn flour, which were termed ártoi tifinoi $i^{61}$.

A supplement to those teachings can be found in book IV of the Collectiones medicae, namely in the chapter Ek tón Galénou, perí paraskeués trofón $n^{62}$, which contains a passage on wheat products, including bread ${ }^{63}$. It is important, because it preserves some supplementary information missing from the chapter inserted in book I of Oribasius' opus magnum. First and foremost the passage enumerates and cursorily discusses three other bread varieties known to Galen, we mean ártos synkomistós (also known as ártos autópyros), i.e. wholemeal bread, ártos rhyparós, that is black bread, and ártos pityrítes, i.e. bran bread. Second, the fragment describes differences in their production, especially addressing the amount of yeast and laboriousness of the kneading involved in bread production. Accordingly, we learn that the whiter the bread, the more leaven and kneading it required.

The other body of data concerning recipes for bread comes from Dieuches' works. However, there are no particularly significant differences between the two Oribasius' authorities, with the exception of one single aspect, namely the issue of the best method of baking. The remaining views and opinions of both physicians are more or less concordant.

\footnotetext{
${ }^{59}$ Cf. K. Jagusiak, M. Kokoszko, Z. RzeźNicka, op. cit., p. 131.

${ }^{60}$ Cf. K. JagusiaK, M. Koкoszko, Z. Rzeźnicka, op. cit., p. 131.

${ }^{61}$ Oribasius, Collectiones medicae, I, 8, 1, 1 - 6, 3; cf. K. Jagusiak, M. Кокоszko, Z. Rzeźnicka, op. cit., p. 131.

${ }^{62}$ Oribasius, Collectiones medicae, IV, $1,1-45,2$.

${ }^{63}$ Oribasius, Collectiones medicae, IV, 3, $1-6,4$.
} 
As for details, Dieuches advised that wheat bread should be made from a flour that does not have an excessive sticky character, and with a small quantity of leaven, which by the bye has a pleasant taste, so that the dough achieved through the process of prolonged kneading would be fairly solid ${ }^{64}$.

As for thermal processing, Dieuches preferred the baking of bread in an ipnós to producing the food in a kríbanon. He also alluded to an ámes as an oven excellent for that purpose. The physician maintained that he postulated such an option for the reason that the process of making bread in an ipnós (and in an ámes, i.e. a cake oven) takes a fairly long time, and bread therein is subject to a temperature that is not excessively high, and, as a result, loaves are not burnt on the outside ${ }^{65}$.

Ártos obtained from a kríbanon, as he opined, is in turn drier than that from an ipnós and, although tastier, baking it in this device is risky, for the crust of bread burns quickly, whereas the interior remains raw $^{66}$.

Subsequently, not having mentioned escharitai, he proceeded direct to enkryphíai. The physician evaluated them as the driest. As for the technology of preparing the food, he stated that its production requires much fuel as well as an appropriate type of wheat. As far as the fuel is concerned, he wrote that it is indispensable to ensure the appropriate quantity of charcoal in order to obtain a large amount of ash, and this aspect of the process is laborious. Moreover, the dough for this purpose has to be kneaded using áleuron flour, and not semídalis. Furthermore, the pastry has to be less solid than that used for bread processed in a kribanon, and this is so, since enkryphías bread is baked by placing and covering it in the (still burning) ashes (which, as we interpret the words, leads to a greater loss of moisture). This method causes scorching (mainly on the surface) and that is why the loaf thus obtained is the driest of all known varieties. Finally, Dieuches introduced in the text his dietetic recommendations, stating that enkryphías is good for those whose alimentary tract is characteristic of an excess of water and therefore inefficient in digesting, and whose intestines accumulate phlegm (phlégma ${ }^{67}$.

Wheat bread was recommended by Dieuches not only as a solid food. As a consequence, he provides a cornucopia of data concerning its utilisation in the preparation of liquid dishes, prescribed first and foremost for the seriously ill (because such food was considered to be much easier to consume and assimilate by them). Judging by the number of references to this subject, the procedure was often profited from in numerous therapies, and the method was used not only to transform bread, but also all other types of cereal foodstuffs. They were cooked in pure water, in a meat (for instance, lamb) broth, or in other types of stock ${ }^{68}$.

\footnotetext{
${ }^{64}$ Oribasius, Collectiones medicae, IV, 5, 1, $1-2,1$.

${ }^{65}$ Oribasius, Collectiones medicae, IV, 5, 2, 1-4.

${ }^{66}$ Oribasius, Collectiones medicae, IV, 5, 3, 1-2.

${ }^{67}$ Oribasius, Collectiones medicae, IV, 5, 4, 1 - 6, 3 .

${ }^{68}$ Oribasius, Collectiones medicae, IV, 7, 10, 3-5.
} 
Although, as for bread, Dieuches maintained that the highest nutritional value is provided by warm, crumbled, and previously soaked loaves ${ }^{69}$, further on in his text he also postulated the boiling of any type of the foodstuff, whether baked with leaven (or not), dry, or fresh ${ }^{70}$.

As regards further recipe details, he wrote that bread should first be soaked, then crushed, and finally strained through a cloth. To the liquid thus obtained one could add roasted wild cucumber seeds, almonds, pine nuts, rowanberries, anise or fennel, and pour some melikraton ${ }^{71}$.

It is interesting that, from time to time, and just as in modern cookbooks, in the text of the Collectiones medicae we can suddenly bump into detailed information referring to the proportions of individual ingredients. For example, for the feverish, the author recommended boiling ten drachms of dried, previously pulverised and subsequently soaked bread in two kotýlai of water, and informs us that the thus obtained rhóphema was mixed with almonds or cucumber seeds ${ }^{72}$. In the next recipe we read that bread was first pounded into grains of the size of semidalis flour or to the size of chóndros, subsequently soaked for a short time, and then ten drachms of these bread groats were boiled in three hemikotýlai of water. The final product was a soup or a gruel, served with honey or other additives ${ }^{73}$.

\section{Dietetic evaluations of bread}

Oribasius' writings also retained a wealth of data on the dietetic aspect of bread, while his main doctrines constitute a derivative of the earlier deliberations penned by Antyllus and Dieuches.

Wheat bread was first and foremost very nutritious (and the quality resulted from the fact that it was obtained from a cereal that represented the same characteristic, i.e. pyrós), but it could have different qualities depending on the variety of wheat from which it was produced. The best in terms of its nutritional value was ártos silignites, i.e. a white bread prepared from sitánios flour ${ }^{74}$. Second in terms of its nutritive value was ártos semidalites, while the third place was allotted to ártos synkomistós. Since the abovementioned classification was consistently included not only in his Collectiones medicae ${ }^{75}$ but also both in Synopsis ad Eustathium

\footnotetext{
${ }^{69}$ Oribasius, Collectiones medicae, IV, 7, 3, 2-3.

${ }^{70}$ Oribasius, Collectiones medicae, IV, 7, 10, 2.

${ }^{71}$ Oribasius, Collectiones medicae, IV, 7, 13, 1 - 14, 4.

${ }^{72}$ Oribasius, Collectiones medicae, IV, 7, 36, 1-4.

${ }^{73}$ Oribasius, Collectiones medicae, IV, 7, 37, 1-4.

${ }^{74}$ Cf. M. Decker, Tilling the Hateful Earth. Agricultural production and trade in the late antique East, Oxford 2011, p. 97, wherein this type of bread is also considered as being the best.

${ }^{75}$ Oribasius, Collectiones medicae, III, 13, 5, 1-6, 1. The chapter concerning products classified as nutritious - Oribasius, Collectiones medicae, III, 13, 1, 1 - 13, 2.
} 
filium $^{76}$ as well as Libri ad Eunapium ${ }^{77}$, it was undoubtedly representative of doctrines accepted by the author.

As for the most distinctive features of the best quality white bread, a full characterisation was included in the those parts of Oribasius' treatises, which contain dietetic categories. Accordingly we learn that kribanites ${ }^{78}$ was allowed in the thinning diet, i.e. leptýnousa díaita ${ }^{79}$, and that this recommendation is a consequence of the inclusion of wheat bread in the class of foods whose features are between those causing the generation of thick juices and contributing to their dilution ${ }^{80}$.

In addition, carefully prepared ártos katharós was characterised by good juices and also caused their generation in the body, and for this reason it was mentioned in the chapter enumerating eúchyma, i.e. foodstuffs generating good bodily humours ${ }^{81}$. Moreover, Oribasius referred to well-kneaded and properly baked wheat ártos amongst substances that were easily digestible ${ }^{82}$. Finally, bread was assessed as a warming food, and this characteristic is evidenced in the third book of the Collectiones medicae, subsequently in the Synopsis ad Eustathium filium, and ultimately in the work dedicated to Eunapius ${ }^{83}$. All of these findings are concordant with Galen's tradition, for in essence they constitute a repetition of his theses included in the De alimentorum facultatibus and other works.

A variety of katharós bread was the so-called ártos plytós. When describing this foodstuff, Oribasius made use of the writings and doctrines of both Galen and Antyllus. As regards the qualities of this bread interpreted by the former writ$e^{84}$, one cannot observe any deviation from the doctrines of the medical doctor

\footnotetext{
${ }^{76}$ OrIbasius, Synopsis ad Eustathium filium, IV, 12, 6, 1-2. The chapter concerning products classified as nutritious - Oribasius, Synopsis ad Eustathium filium, IV, 12, 1, 1 - 15, 2.

${ }_{77}$ Oribasii Libri ad Eunapium, I, 29, 1, 1 - 15, 2 (light bread - I, 29, 6, 1 - 7, 1), [in:] Oribasii synopsis ad Eustathium filium et libri ad Eunapium, ed. I. RAEDER, vol. VI, 3, Leipzig 1964 (cetera: OrIBASIUS, Libri ad Eunapium).

${ }^{78}$ Oribasius, Collectiones medicae, III, 2, 5, 2-3.

${ }^{79}$ Oribasius, Collectiones medicae, III, 2, 1, 1-26, 2.

${ }^{80}$ Oribasius, Collectiones medicae, III, 4, 1, 1-14 ( wheat bread - III, 4, 1, 1); OrIBAsIus, Synopsis ad Eustathium filium, IV, 3, 1, 1-15 (wheat bread - IV, 3, 1, 1); OrIBAsıus, Libri ad Eunapium, I, 20, 1, 1-14 (wheat bread - I, 20, 1, 1).

${ }^{81}$ Oribasius, Collectiones medicae, III, 15, 1, 1 - 22, 3 (wheat bread - III, 15, 18, 1); Oribasius, Synopsis ad Eustathium filium, IV, 14, 1, 1 - 21, 3 (wheat bread - IV, 14, 17, 1); OrIBASIUs, Libri ad Eunapium, I, 32, 1, 1 - 15, 3 (wheat bread - I, 32, 11, 1 - 12, 1).

${ }^{82}$ Oribasius, Collectiones medicae, III, 17, 1, 1 - 11, 1 (wheat bread - III, 17, 1, 1); Oribasius, Synopsis ad Eustathium filium, IV, 16, 1, 1 - 11, 1 (wheat bread - IV, 16, 1, 1); OrIBasius, Libri ad Eunapium, I, 34, 1, 1 - 11, 2 (wheat bread - I, 34, 1, 1).

${ }^{83}$ Oribasius, Collectiones medicae, III, 31, 1, 1 - 8, 3 (wheat bread - III, 31, 1, 1); Oribasius, Synopsis ad Eustathium filium, IV, 31, 1, 1 - 8, 4 (wheat bread - IV, 31, 1, 1); OrIBAsIUs, Libri ad Eunapium, I, 47, 1, 1-9 (wheat bread - I, 47, 1, 1).

${ }^{84}$ Oribasius, Collectiones medicae, I, 8, 3, $1-4,1$.
} 
of Pergamum ${ }^{85}$. Therefore, we shall not return to them. Additionally, the most prominent characteristics of this kind of bread taken from Galen's writings are present in the lists of foodstuffs collected by Oribasius according to their predominant dietetic qualities. Ártos plytós was therefore mentioned in the third book of the Collectiones medicae as one of the foods displaying features that were intermediate between warming and cooling ${ }^{86}$, and an identical characterisation may be found in other treatises ${ }^{87}$. Finally, light bread is included in Oribasius' category of foods that give the body little nourishment ${ }^{88}$.

As for Antyllus' discussion, he described the action of the said cereal product in his work Perí boethemáton, in the fragment on the food appropriate for those who suffer from frequent ailments ${ }^{89}$. There we can read that such people should consume food that easily ripens in their stomachs, is easily assimilated, but not excessively nutritious, and in addition readily excreted from the body through perspiration. Other kinds, and especially if they were to remain in the body for an extended period of time, would lead to a fever. Since, once the bodily temperature had been morbidly raised, Antyllus prescribed ártos plytós boiled to a pulp in water, one can conclude that it was exactly that kind which satisfied all of the conditions enumerated above ${ }^{90}$.

Ártos synkomistós did not receive a proper and separate dietetic characterisation in any work penned by the Emperor Julian's friend. However, from the doctrines of Galen borrowed by Oribasius it is clear that it was in between the qualities of white and bran bread. Accordingly, it was fairly nutritious, quite easily digested and contributed fairly efficiently to the production of good quality humours.

On the other hand, Oribasius makes remarks referring to black bread. The author stressed only one of dietetic features. Namely, he mentioned that ártos rhyparós, differed considerably in minus in terms of nutritive value from katharós. Therefore, he specified its limited nutritional value products first in his Collectiones medicae, and subsequently in the work dedicated to his son, and the one compiled for Eunapius ${ }^{11}$.

\footnotetext{
${ }^{85}$ They were cursorily mention in our discussion of res coquinaria concerning bread.

${ }^{86}$ Oribasius, Collectiones medicae, III, 32, 1, 1 - 12, 3 (light bread - III, 32, 12, 2).

${ }^{87}$ Oribasius, Synopsis ad Eustathium filium, IV, 32, 1, 1 - 13, 2 (light bread - IV, 32, 13, 1-20; Oribasius, Libri ad Eunapium, I, 48, 1, 1 - 7, 3 (light bread - I, 48, 7, 1-2).

${ }^{88}$ Oribasius, Collectiones medicae, III, 14, 1, 1 - 13, 3 (light bread - III, 14, 7, 2); Oribasius, Synopsis ad Eustathium filium, IV, 13, 1, 1 - 12, 4 (light bread - IV, 13, 6, 2); Oribasius, Libri ad Eunapium, I, 30, 1, 1 - 8, 2 (light bread - I, 30, 6, 2).

${ }^{89}$ Oribasius, Collectiones medicae, IV, 11, $1.1-14,4$.

${ }^{90}$ Oribasius, Collectiones medicae, IV, 11, 1, 1 - 2, 1 .

${ }^{91}$ Oribasius, Collectiones medicae, III, 14, 1, 1 - 13, 3 (black bread - III, 14, 7, 2); OrIBAsIus, Synopsis ad Eustathium filium, IV, 13, 1, 1 - 12, 4 (black bread - IV, 13, 6, 1-2); OribasIUs, Libri ad Eunapium, I, 30, 1, 1 - 8, 2 (black bread - I, 30, 6, 2).
} 
The dietetic properties of the bread known as pityrites are described in the physician's writings in somewhat greater detail. The author emphasised three of its most important qualities. The first was its limited nutritional value ${ }^{92}$. The second constituted its purgative strength ${ }^{93}$. The third was its action stimulating the generation of black bile ${ }^{94}$.

Unfortunately, Oribasius' works lack a separate characterisation of unleavened bread. Having in mind the logic of his doctrine, one may, however, conclude that its qualities were the opposite of those attributed to ártos katharós.

In turn, ártos chondrites, since it was made from chóndros, had the same qualities as the groats. It was therefore considered highly nutritious, but also one that is slow and difficult to pass through the alimentary tract ${ }^{95}$.

Finally, information included in Oribasius' writings teaches the reader that the nutritional value of bread was determined by the difference in baking techniques used in its making, with ártoi made in the kríbanon or ipnós being presented as the most wholesome, while those subject to thermal processing on the eschára and in the ashes were evaluated as inferior.

\section{Medical applications of bread}

Starting our reflections on different therapeutic uses of bread, it is worth noting that the texts of Oribasius do not contain a single prohibition on the consumption of the foodstuff in any prescribed cure. This stems from the fact that the product was generally classified as contributing to the health of its consumers. As a result, it was appropriate for any diet including even those which were designed for the naturally prone to frailty due to their advanced age ${ }^{96}$.

The recommendation to consume wheat bread may, however, be encountered not only in the diets prescribed to those who were already well-past their prime. For instance, the white variety baked in the ipnós (due to the fact that it retained more moisture than other kinds) was recommended by Ruphus of Ephesus (I c.) in his chapter (preserved in the Collectiones medicae) on foods to be consumed in order to lead a satisfying sexual life, since such foodstuffs better contributed

\footnotetext{
${ }^{92}$ Oribasius, Collectiones medicae, III, 14, 1, 1 - 13, 3 (pityrítes - III, 14, 7, 1); Oribasius, Synopsis ad Eustathium filium, IV, 13, 1, 1 - 12, 4 (pityrítes - IV, 13, 6, 1); Oribasius, Libri ad Eunapium, I, 30, 1, $1-8,2$ (pityrites - I, 30, 6, 1-2).

${ }^{93}$ Oribasius, Collectiones medicae, III, 29, 1, 1 - 22, 2 (pityrites - III, 29, 4, 1); Oribasius, Synopsis ad Eustathium filium, IV, 28, 1, 1 - 27, 2 (pityrites - IV, 28, 5, 1); Oribasıus, Libri ad Eunapium, I, 45, 1, 1 - 17, 1 (pityrites - I, 45, 5, 1).

${ }^{94}$ Oribasius, Collectiones medicae, III, 9, 1, 1 - 2, 5 (pityrites - III, 9, 2, 2-3); OrIbasius, Synopsis ad Eustathium filium, IV, 8, 1, 1 - 2, 5 (pityrites - IV, 8, 2, 2-3); Oribasius, Libri ad Eunapium, I, 25, $1,1-2,4$ (pityrítes - I, 25, 2, 2).

${ }_{95}$ Oribasius, Collectiones medicae, I, 5, 2, 1-2.

${ }^{96}$ For example - Oribasius, Libri ad Eunapium, I, 11, 1, 1 - 19, 3 (bread - I, 11, 4, 2).
} 
to bodily humidity (which, apart from warmth) was the prerequisite for intensive sexual intercourse (and typically characteristic of young persons) ${ }^{97}$.

In the part of our discussion of res coquinaria concerning bread we alluded to the fact that bread was often recommended to be served both solid, moistened, and transformed into a soup. Much was written on the subject by Dieuches and a lot was also explained by Antyllus ${ }^{98}$. we have already pointed to the latter's information on the preparation of ártos plytós for the ill. In turn, since semidalites was classified as having too strong an effect on the seriously and chronically ailing, it was indispensable to select stale and well-leavened bread of this kind, and scoop the inside of a loaf, which subsequently had to be thoroughly moistened with warm water (for the hard crust is too difficult to eat and digest). The bread should be soaked until its volume increases and the yeast is washed out (which one can learn the moment when it loses the smell of leaven $)^{99}$. We should surmise that the described practice was considered to be therapeutically effective, for Oribasius returns to the doctrines of Antyllus in Synopsis ad Eustathium filium ${ }^{100}$.

The treatises of Oribasius clearly prove that in the medical science of the fourth century, bread was not only an important element of medicinal diets, but also an ingredient of numerous medications. Such applications are so numerous that it is best to resort to just a few examples. For instance, in the chapter concerning clysters ${ }^{101}$, which contains Ruphus' of Ephesus teachings, Oribasius included a concoction (aphépsema) from bread ${ }^{102}$ amongst the group of enemas with a mild action (hapaloi klystéres) ${ }^{103}$. From the text we learn that bread clysters were generally obtained by means of boiling it, and had a certain nutritive action. We are also informed that they were used (once the intestines had been purified of excrement) for persons with severe crises brought about by paralysis and cardiac problems (as these patients usually have problems with food assimilation and their intestines are blocked with the products of metabolism) ${ }^{104}$.

It should be added that bread was also used to prepare therapeutic gargles. For example, when a patient suffered from sore throat and the illness led to the formation of painful eruptions in the throat (anadorá), it was recommended to wash the throat with warm liquor left over from soaking bread (apóbregma) ${ }^{105}$.

\footnotetext{
${ }_{97}$ Oribasius, Collectiones medicae, VI, 38, 1, 1 - 30, 5 (qualities of the bread - VI, 38, 15, 5-6); humidity and warmth - VI, 38, 9, 1-2).

${ }^{98}$ Oribasius, Collectiones medicae, IV, 11, $1.1-14,4$.

${ }^{99}$ Oribasius, Collectiones medicae, IV, 11, 2, 3-3, 1.

${ }^{100}$ Oribasius, Synopsis ad Eustathium filium, IV, 37, 1, 1- 9, 2 (wetting of the stale bread and removal of yeast - IV, 37, 2, 1-4, 1).

${ }^{101}$ Oribasius, Collectiones medicae, VIII, 24, 1, 1 - 39, 3.

${ }^{102}$ Oribasius, Collectiones medicae, VIII, 24, 1, 4.

${ }^{103}$ Oribasius, Collectiones medicae, VIII, 24, 1, 2-3, 1.

${ }^{104}$ Oribasius, Collectiones medicae, VIII, 24, 13, 1 - 14, 2.

${ }^{105}$ Oribasius, Eclogae medicamentorum, 35, 1, 1 - 4, 6 (liquor - 35, 1, 6).
} 
Bread, however, is discussed first and foremost as an ingredient of poultices, and Oribasius' treatises preserve a cornucopia of information on their composition and applications. The said medicinal substance was so significant in his times that bread cataplasms received a separate chapter in the Collectiones medicae ${ }^{106}$, which was excerpted from the writings of Lycus (I c. BC) ${ }^{107}$. Accordingly, bread poultices were thought to act effectively against a variety of inflammations ${ }^{108}$, and were prepared in a great many varieties. The author commenced their listing by stating that such medicaments may be obtained by adding some rose oil to bread soaked in cold water. Such medicines were regarded as effective in the treatment of conditions similar to erysipelas (erysipelas) ${ }^{109}$. Another recipe provided for the soaking of bread in oxýkraton, and the poultice was supposed to be even more efficient in its healing action for the said ailment than the former ${ }^{110}$. A bread cataplasm could also be made by dipping the foodstuff in hot water and adding olive oil, while the medicament was thought to soften inflammations which brought about swellings that occurred without suppuration ${ }^{111}$. Continuing his text, the physician remarked that butter can be substituted for olive oil with no harm to the curative properties of the medicine whatsoever ${ }^{112}$. In turn, another kind of cataplasm was produced as follows. Bread was mixed with water into a liquid form, to which olive oil or butter was added, and the gruel was boiled until it acquired the appropriate thickness ${ }^{113}$. The medication was considered a very good drug for the treatment of inflammations brought about by physical injury (since it facilitated the excretion of pus from ulcerated wounds) ${ }^{114}$, moreover, (with some tar addition) it could have beneficial effects on tendon contusion, and finally was appropriate in gout treatment ${ }^{115}$. Another method of preparing bread cataplasms was based on pulverising the inside of a loaf to the consistency of áleuron flour. The powder thus obtained was mixed with honey and a small quantity of water ${ }^{116}$, and subsequently boiled to the appropriate thickness to be ultimately enriched with some olive oil ${ }^{117}$.

\footnotetext{
${ }^{106}$ Oribasius, Collectiones medicae, IX, 26, 1, 1 - 10, 3.

${ }^{107}$ On Lycus life see E. KInd, Lykos (51), [in:] RE, Bd. XIII, 2, Stuttgart 1927, col. 2407-2408; A. TouWAIDE, Lycus (10), [in:] Brill's New Pauly..., vol. VII, Leiden-Boston 2005, col. 938-939.

${ }^{108}$ Oribasius, Collectiones medicae, IX, 26, 1, 2.

${ }^{109}$ Oribasius, Collectiones medicae, IX, 26, 1, 2 - 2, 1.

${ }^{110}$ Oribasius, Collectiones medicae, IX, 26, 2, 1 - 3, 1 .

${ }^{111}$ Oribasius, Collectiones medicae, IX, 26, 3, 1 - 4, 1.

112 Oribasius, Collectiones medicae, IX, 26, 4, 1-2.

${ }^{113}$ Oribasius, Collectiones medicae, IX, 26, 5, 1-3.

${ }^{114}$ Oribasius, Collectiones medicae, IX, 26, 5, 3 - 6, 1.

115 Oribasius, Collectiones medicae, IX, 26, 6, 1 - 8, 1.

${ }^{116}$ OrIBasius, Collectiones medicae, IX, 26, 9, 1 - 10, 1 .

${ }^{117}$ Oribasius, Collectiones medicae, IX, 26, 8, 1-5.
} 
Such poultices were said to cure hypochóndria ailments ${ }^{118}$. we should also remark that an analogous passage concerning the nature of bread poultices is repeated in his Synopsis ad Eustathium filium ${ }^{119}$.

\section{Conclusion}

In conclusion, we would like to underline the fact that medical sources, including the treatises penned by Oribasius, constitute a vast body of information on bread as food and medicine, which, in turn, is part of an ancient system of medical knowledge.

Oribasius' interest in food resulted from the doctrine adopted by all ancient and later medical doctors who used to treat any foodstuff as both a provider of nutrients as well as a factor that shapes the internal balance of the human body. The adoption of the view led to the development of dietetics which worked out a cohesive system of evaluation of foodstuffs according to their most important features, and categorising methods of food preparation able to modify its properties in line with individual health requirements. Therefore those who practised and theorised on medicine started to become interested in and had to be knowledgeable about the art of food preparation, i.e. gastronomy. So did Oribasius as a faithful follower of the ancient, particularly Galenic, tradition.

As a result, the medical theory (and also that presented by the Emperor Julian's friend) is much richer than mere dietetic deliberations and also refers to the state of food production (I mean the range of foodstuffs produced by the agriculture of the period and methods of their production) and food processing techniques (that is methods utilised in order to preserve a foodstuff or transform it into a dish), which were both thought to have an impact upon the quality of foodstuffs prescribed by the doctor to his patients as well those included in composed medicaments. The resulting output, as it has been demonstrated, is a readily available corpus of material, which still waits to be analysed, not only by historians of medicine (first of all dieticians, bromatologists and pharmacologists), but also by those interested in food history, ancient and medieval economy historians, as well as those researching the history of society.

It is to be hoped that in the very near future the resources of information will be subject to even more thorough research on a wider scale.

\footnotetext{
${ }^{118}$ Oribasius, Collectiones medicae, IX, 26, 8, 5 - 9, 1.

${ }^{119}$ Oribasius, Synopsis ad Eustathium filium, III, 78, 1, 1 - 7, 3.
} 


\section{Bibliography}

\section{Sources}

Athenaei Naucratitae dipnosophistarum libri XV, rec. G. KAIBEL, vol. I-III, Lipsiae-Berolini 1887-1890.

Dioscuridis Peri haplon farmakon, [in:] Pedanii Dioscuridis Anazarbei De materia medica libri quanque, ed. M. Wellmann, vol. I-III, Berolini 1914.

Galeni de alimentorum facultatibus, [in:] Claudii Galeni opera omnia, ed. D.C.G. KüHN, vol. VI, Lipsiae 1823.

Galeni De victu attenuante, ed. K. KALBFLEISCH, Leipzig-Berlin 1923.

Hippocrate, De alimento, [in:] Euvres completes d'Hippocrate, ed. E. Littre, vol. IX, Amsterdam 1962.

Hippocratis de diaeta, ed. R. Joly, S. ByL, Berlin 2003.

Homerus, Odyssea, [in:] Homerus, Homerica carmina, ed. A. Nauck, vol. II, Berolini 1874.

Oribasii collectionum medicarum reliquiae, ed. I. RAEDER, vol. I-IV, Lipsiae-Berolini 1928-1933.

Oribasius, Synopsis ad Eustathium filium, [in:] Oribasii synopsis ad Eustathium filium et libri ad Eunapium, ed. I. RAEDER, Leipzig 1964.

Paulus Aegineta, ed. I.L. Heiberg, Leipzig-Berlin 1921.

Pedanii Dioscuridis Anazarbei De materia medica libri V, ed. M. Wellmann, vol. I-III, Berolini 1906-1914.

Photius. Bibliotheque, ed. R. Henry, vol. I-VIII, Paris 1959-1977.

Pliny, Natural history, transl. H. Rackham, W.H.S. Jones, D.E. EichHolz, vol. I-X, Cambridge, Mass. 1938-1963.

Suidae lexicon, ed. A. AdLER, vol. I-IV, Lipsiae 1928-1935.

Theodoretus, Historia religiosa, [in:] Théodoret De Cyr, Histoire des moines de Syrie, vol. I-II, trad. P. Canivet, A. Leroy-Molinghen, Paris 1977-1979.

\section{Secondary literature}

Anagnostakis I., The Loaves of the King and the Loaves of Cinderella. Byzantine Tales of Bread in Silk and in Ash, [in:] ...come sa di sale lo pane altrui Il Pane di Matera e i Pani del Mediterraneo Atti del Convegno Internazionale di Studio promosso dall'IBAM-CNR nell'ambito del Progetto MenSALe Matera, 5-7 Settembre 2014, ed. A. Pelletieri, Foggia 2014, p. 115-122.

BALDwin B., The career of Oribasius, AClas 18, 1975, p. 85-97.

Bednarczyк A., Galen. Główne kategorie systemu filozoficzno-lekarskiego, Warszawa 1995.

Bergoldt K., Wellbeing. A cultural history of healthy living, transl. J. Dewhurst, Cambridge-Malden, Mass. 2008.

BRALEWski S., Od obżarstwa do postu - praktykowanie wstrzemięźliwości od pokarmu przez chrześcijan do VII w., [in:] Dietetyka i sztuka kulinarna antyku i wczesnego Bizancjum (II-VII w.), cz. II, Pokarm dla ciała i ducha, ed. M. Koкоszko, Łódź 2014, p. 463-521.

ByL S., L'alimentation dans le Corpus Hippocratique, [in:] Voeding en geneeskunde / Alimentation et médecine. Acten van het colloquium / Actes du colloque Brussel-Bruxelles 12.10.1990, ed. R. JANSen-Sieben, F. Daelmans, Brussels 1993, p. 29-39. 
Craik E., Hippocratic diaita, [in:] Food in antiquity, ed. J. Wilkins, D. Harvey, M. Dobson, Exeter 1999, p. 343-350.

CubBerley A., Bread-baking in ancient Italy. Clibanus and sub testu in the Roman world: Further thoughts, [in:] Food in antiquity, ed. J. Wilkins, D. Harvey, M. Dobson, Exeter 1999, p. 55-68.

Dalby A., Food in the ancient world from A to Z, London-New York 2003.

DALBy A., Flavours of Byzantium, Blackawton-Totnes 2003.

Decker M., Tilling the Hateful Earth. Agricultural production and trade in the late antique East, Oxford 2011.

Dembińska M., Diet: A comparison of food consumption between some Eastern and Western monasteries in the $4^{\text {th }}-12^{\text {th }}$ centuries, B 55, 1985, p. 431-462.

ERdкAmp P., The grain market in the Roman Empire. A social, political and economic study, Cambridge 2005.

ERdKamp P., Supplying cities, [in:] A companion to food in the ancient world, ed. J. WiLkins, R. Nadeau, Malden, Mass.-Oxford 2015, p. 183-192.

Forbes R.J., Studies in ancient technology, vol. III, Leiden 1965.

Garcia Gaul C., Dieta hipocrática y prescripciones alimentarias de los pitagóricas, [in:] Dieta Mediterránea, Comidas y hábitos alimenticios en las culturas Mediterráneas, ed. A. PÉrez Jiménez, G. Cruz Andreotti, Madrid 2000, p. 43-68.

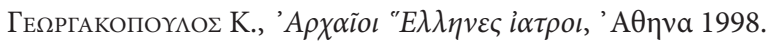

Grant M., Oribasios and medical dietetics or the three ps, [in:] Food in antiquity, ed. J. Wilkins, D. Harvey, M. Dobson, Exeter 1999, p. 368-379.

A Greek-English lexicon, ed. H.G. Liddell, R. Sсотт, Oxford 1996.

Hankinson R.J., The man and his work, [in:] The Cambridge companion to Galen, ed. R.J. Hankinson, Cambridge 2008, p. 1-33.

Harlan J.R., The origins of cereal agriculture in the Old World, [in:] Origins of agriculture, ed. C.A. ReEd, the Hague-Paris 1977, p. 357-384.

Hunter R., Koukouzika D., Food in Greek literature, [in:] A companion to food in the ancient world, ed. J. Wilkins, R. Nadeau, Malden, Mass.-Oxford 2015, p. 19-29.

Ieraci Bio A.M., Antyllos, [in:] Antike Medizin. Ein Lexikon, hrsg. K.-H. Leven, München 2005, col. 62-63.

Jagusiak K., Koкоszко M., Życie i kariera Orybazjusza w świetle relacji źródłowych, PNH 10. 1, 2011, p. 5-21.

Jagusiak K., Kокоszкo M., Pisma Orybazjusza jako źródło informacji o pożywieniu ludzi w późnym Cesarstwie Rzymskim, VP 33 (59), 2013, p. 339-357.

Jagusiak K., Kокоszкo M., Rzeźnicka Z., Cakes and breads in Oribasius' Collectiones medicae, SPP 25. 1, 2015, p. 127-140.

JASNY N., The daily bread of the ancient Greeks and Romans, Osi 9, 1950, p. 227-253.

JouANNA J., Le régime dans la médecine hippocratique: définition, grands problèmes, prolongements, [in:] Colloque. Pratiques et discours alimenatires en Méditerranée de l'antiquité a la renaissance. Actes, ed. J. Leclant, A. Vauchez, M. Sartre, Paris 2008, p. 53-72.

JouAnNa J., Greek medicine from Hippocrates to Galen, Leiden-Boston 2012.

Kessler D., Termin P., The organization of the graint trade in the early Roman Empire, EcHR 60, 2007, p. 313-332. 
KInd E., Lykos (51), [in:] RE, Bd. XIII, 2, Stuttgart 1927, col. 2407-2408.

Koder J., Stew and salted meat - opulent normality in the diet of every day?, [in:] Eat, drink and be merry (Luke 12:19). Food and wine in Byzantium. In honour of Professor A.A.M. Bryer, ed. L. BRUBAKER, K. Linardou, Aldershot, Hampshire 2007, p. 59-72.

Кокоszко M., Ryby i ich znaczenie w życiu codziennym ludzi późnego antyku i Bizancjum (IV-VII w.), Łódź 2005.

Koкoszko M., DybaŁa J., Jagusiak K., Rzeźnicka Z., Dieta mnichów syryjskich. Komentarz do terminu ospria (ö $\sigma \pi \rho \iota \alpha) w$ Historia religiosa Teodoreta $z$ Cyru, BPT 7.1, 2014, p. 115-143.

Кокоszко M., DyвaŁa J., Jagusiak K., Rzeźnicka Z., Dieta mnichów syryjskich. Komentarz do

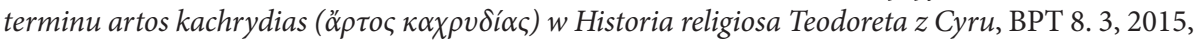
p. $123-156$.

Koкoszko M., Dyba£a J., Jagusiak K., RzeźNicka Z., Chleb nieodpowiedni dla chrześcijan: moralne zalecenia Klemensa Aleksandryjskiego w konfrontacji z naukowymi ustaleniami Galena, VP 35, p. 249-291.

Kокоszко M., Jagusiak K., Zboża Bizancjum. Kilka uwag na temat roli produktów zbożowych na podstawie źródeł greckich, ZW 17, 2012, p. 19-38.

Kокоszко M., Jagusiak K., Rzeźnicka Z., Cereals of antiquity and early Byzantine times. Wheat and barley in medical sources (second to seventh centuries $A D$ ), transl. K. WODZIŃsKa, M. ZAKrzewSKI, M. ZyTKa, Łódź 2014.

Kокоszкo M., Jagusiak K., RzeźNicka Z., Dietetyka i sztuka kulinarna antyku i wczesnego Bizancjum (II-VII w.), cz. I, Zboża i produkty zbożowe w źródłach medycznych antyku i wczesnego Bizancjum, Łódź 2014.

Kron G., Agriculture, [in:] A companion to food in the ancient world, ed. J. Wilkins, R. Nadeau, Malden, Mass.- Oxford 2015, p. 160-172.

Kulf E., Unterschungen zu Athenaios von Attaleia. Ein Beitrag zur antiken Diätetik, Göttingen 1970.

LeIGH M., Food in Latin literature, [in:] A companion to food in the ancient world, ed. J. WiLKINS, R. NAdEAU, Malden, Mass.-Oxford 2015, p. 43-52.

Leven K.-H., Athenaios v. Attaleia, [in:] Antike Medizin. Ein Lexikon, hrsg. K.-H. Leven, München 2005, col. 119-120.

Liversidge J., Roman kitchens and cooking utensils, [in:] The Roman cookery book. A critical translation of The art of cooking by Apicius for use in the study and in the kitchen, ed. and transl. B. Flower, E. Rosenbaum, London 1958, p. 28-38.

De Lucia R., Oreibasios v. Pergamon, [in:] Antike Medizin. Ein Lexikon, ed. K.-H. Leven, München 2005, col. 660-661.

de Lucia R., Oribasio di Pergamo, [in:] A. Garzya, R. de Lucia, A. Guardasole, A.M. Ieraci Bio, M. Lamagna, R. Romano, Medici byzantini. Oribasio di Pergamon. Aezio d' Amida. Alessandro di Tralle. Paolo d'Egina. Leone medico, Torino 2006, p. 21-29.

McGee H., On food and cooking. The science and lore in the kitchen, New York 2004.

Morley N., Trade in classical antiquity, Cambridge 2007.

Nutton V., Galen and medical autobiography, PCPS 198 (New Series no. 18) 1972, p. 50-62.

NutTon V., The chronology of Galen's early career, CQ 23, 1973, p. 158-171.

NutTon V., Galen in the eyes of his contemporaries, BHM 58, 1984, p. 315-324.

Nutton V., Galen and the traveller's fare, [in:] Food in antiquity, ed. J. Wilkins, D. Harvey, M. Dobson, Exeter 1999, p. 359-370. 
Nutton V., Antyllus, [in:] Brill's New Pauly. Encyclopaedia of the Ancient World, vol. I, Leiden-Boston 2002, col. 810-811.

Nutton V., Athenaeus (6), [in:] Brill's New Pauly. Encyclopaedia of the Ancient World, vol. II, LeidenBoston 2003, col. 244-245.

Nutton V., Ancient medicine, London-New York 2007.

Pucci Donati F., Dieta, salute, calendari. Dal regime stagionale antico ai regimina mensium medievali: origine di un genere nella letterature medica occidentale, Spoleto 2007.

Rautman M.L., The daily life of the Byzantine Empire, Westport 2006.

Rickman G.E., The grain trade under the Roman Empire, [in:] The seaborne commerce of ancient Rome. Studies in history and archaeology, ed. J.H. D’Arms, E.C. KopfF, Rome 1980, p. 261-275.

SARTON G., Galen of Pergamon, Lawrence, KS, 1954.

Scarborough J., Theoretical assumptions in Hippocratic pharmacology, [in:] Formes de pensée dans la collection hippocratique. Actes du IV Colloque International Hippocratique, Lausanne, September 1981, ed. F. Lasserre, P. Mudry, Geneva 1983, p. 307-325.

Sparkes B., The Greek kitchen, JHS 82, 1962, p. 121-137.

Sparkes B., The Greek kitchen: Addenda, JHS 85, 1965, p. 162-163.

Tengström E., Bread for the people. Studies of the corn-supply of Rome during the Late Empire, Stockholm 1974.

Thorndike L., Galen. The man and his times, ScM 14, 1922, no. 1, p. 83-93.

Thurmond D., A handbook of food processing in classical Rome. For her bounty no winter, LeidenBoston 2006.

Touwaide A., Lycus (10), [in:] Brill's New Pauly. Encyclopaedia of the Ancient World, vol. VII, LeidenBoston 2005, col. 938-939.

Volpe Cacciatore P., El régimen según Galeno, [in:] Dieta Mediterránea. Comidas y hábitos alimenticios en las culturas Mediterráneas, ed. A. Pérez Jiménes, G. Cruz Andreotti, Madrid 2000, p. 91-101.

Wellmann M., Athenaios aus Attalia, [in:] RE, Bd. II, Stuttgart 1896, col. 2034-2036.

Wellmann M., Dieuches (3), [in:] RE, Bd. V, Stuttgart 1905, col. 480.

White K.D., Cereals, bread and milling in the Roman world, [in:] Food in antiquity, ed. J. WiLkins, D. Harvey, M. Dobson, Exeter 1999, p. 38-43.

Zohary D., Hopf M., Domestication of Plants in the Old World. The origin and spread of cultivated plants in West Asia, Europe and the Nile Valley, Oxford 1993.

\footnotetext{
Abstract: Treatises left by Oribasius (first and foremost his Collectiones medicae and Eclogae medicamentorum) preserve a vast body of information on the varieties of bread eaten in late antiquity, characterise them from the point of view of dietetics, list medical conditions in which a given variety is especially beneficial, and name medical preparations which include the product. The present study elaborates on Oribasius' dietetic knowledge and his input into the development of dietetic discourse (namely his influence on Byzantine dietetic doctrine), determines Oribasius' main information sources on bread, characterises bread as food, lists varieties which were thought to be used by physicians and explains reasons for the preferences, and finally exemplifies cures and medical preparations which include bread.
} 
Keywords: Oribasius; history of ancient and Byzantine medicine; ancient and Byzantine food history; ancient and Byzantine dietetics; ancient and Byzantine drug-lore; bread; cereals.

Maciej Kokoszko

Uniwersytet Łódzki

Wydział Filozoficzno-Historyczny

Instytut Historii

Katedra Historii Bizancjum

ul. Kamińskiego 27a

91-201 Łódź, Polska/Poland

mkokoszko@komandor.pl

Krzysztof Jagusiak

Centrum Badań nad Historią i Kulturą

Basenu Morza Śródziemnego

i Europy Południowo-Wschodniej

im. prof. Waldemara Cerana, Ceraneum UŁ

ul. Matejki 32/38, sala 319

90-237 Łódź, Polska/Poland

krzysztof_jagusiak@o2.pl

Jolanta Dybała

Uniwersytet Jana Kochanowskiego

Filia w Piotrkowie Trybunalskim, Biblioteka

ul. J. Słowackiego 114/118

97-300 Piotrków Trybunalski, Polska/Poland

j.dybala@vp.pl 